ISSN 2078-6441. Вісник Львівського університету. Серія географічна. 2018. Випуск 52. С. 132-142.

Visnyk of the Lviv University. Series Geography. 2018. Issue 52. P. 132-142.

http:/ / dx.doi.org/10.30970/vgg.2018.52.10179

$338.48-6: 2-522$

\author{
ндрій ов льчук, ндрій нько \\ ьвівський н ціон льний університет імені в н \\ вул. . орошенк , 41, 79007, м. ввів, кр їн, \\ e-mail: KovalchukAS@i.ua,manko_a@ukr.net
}

ро н лізов но особливості функціонув ння орг ніз торів релігійно-п ломницького туризму. исвітлено особливості язичництв в кр їні як потенці лу для розвитку релігійного туризму.

тучний термін “язичник" позн ч є вірного своєї втентичної релігії, відмінної від вр мічних релігій: іуд їзму, християнств , ісл му. світі н лічується 400-500 млн язичників. х поділяють н т кі групи: 1) первісні, чи втохтонні, культи - поширені перев жно серед корінних н родів зії, фрики, мерики, встр лії т ке нії й вирізняються глибокими історичними коріннями, зберегли цілісність політеїстичного релігійного світогляду свого етносу; 2) предст вники "побутового" язичництв, що в більше чи менше поєднують окремі елементи д вніх вірув нь (ворожіння, м гію, культ предків, культ природи т ін.) з певною вр мічною релігією; 3) групи прихильників здорового способу життя в г рмонії з природою, для язичницьких вірув нь х $\mathrm{p}$ ктерний зн чний синкретизм з природоохоронними вченнями; 4) конфесії, що поєднують втохтонну релігію свого н роду з його теперішніми політичними цілями. $\quad$ г лом язичництво є однією 3 н йменш гресивних релігій світу.

кр їнські язичники (рідновіри, родовіри) н лічують близько 150 гром д у всіх регіон х кр їни. йбільш їхня кількість діє у інницькій, мельницькій, порізькій, ніпропетровській, олт вській, ьвівській обл стях т у иєві. пон д сотні священнослужителів-язичників нем $є$ жодного іноземця, - явище не типове для більшості укр їнських конфесій. зичництво корінн релігія укр їнців, що відстоює втентичність н шого суспільств т держ ви.

н шими підр хунк ми, в кр їні відомо пон д 100 язичницьких святинь: діючих чи д вніх, більш чи менш збережених т впорядков них, більш чи менш тр ктивних для туристів й екскурс нтів. оділля, одніпров'я, рп ти, олісся м ють н йбільшу концентр цію язичницьких святинь - культових об'єктів нтропогенно-природного т природного походження: святилищ, к пищ, жертовників, требищ, печер, скель, мег літів (дольменів, кромлехів, менгірів), петрогліфів, кург нів, дерев, джерел, ідолів, п нтеонів тощо. роте більшість із цих об'єктів не відомі широкому з г лу бо відомі не як язичницькі святині, як природні чи історико-культурні об'єкти.

ля поінформов ності суспільств потрібно орг нізув ти рекл мно-інформ ційну к мп нію $з$ цього пит ння. еобхідно припинити упереджене, ч сто вороже ст влення до язичництв предст вників окремих релігій, винищув ння язичницьких святинь і впорядкув ти їх для туристичної доступності. еоднор зове висвітлення етнічно-релігійного т культурно-цивіліз ційного зн чення укр їнських язичницьких святинь підсилюв тиме вже відому про них інформ цію і дод в тиме до потоку м ндрівників релігійних туристів т збільшув тиме кількість п ломників.

лючові слов : язичництво, пог нство, вр мічні релігії, орг ніз ція релігійного туризму, язичництво в кр їні, орг ніз ція п ломництв , релігійний туризм в кр їні

(C) ов льчук ., нько ., 2018 
релігієзн встві під язичництвом (від церковнослов’ янського “язики” - н роди), бо пог нством (від л т. paganus - житель сільської місцевості, ідолопоклонник), розуміють тр диційну релігію певного н роду, що не вписується у р мки вр мічних релігій. ермін “ вр мічні ( вр мічні, вр містичні) релігії” походить від н зви родон ч льник ст род вніх євреїв - біблійного вр м, що р зом із родиною вирушив із есопот мії (суч сний р к), щоб н з вжди оселитися н землях суч сного зр їлю. рім вл сне іуд їзу, до вр мічних релігій н леж ть дві світові релігії: християнство т ісл м, т кож похідні від них (іудео-християни, друзи, к р їми, єзиди т ін.), що в основі $\epsilon$ монотеїстичними. онотеїзм - релігія, що передб ч є віру в одного бог , н відміну від політеїстичних релігій (вір в б г тьох богів), яких вл сне й н зив ють язичницькими.

оч не всі язичницькі течії є політеїстичними. прикл д, ідн кр їнськ ціон льн ip ( ip ) є монотеїстичною неорелігією н чолі з жбогом.

редст вники групи вр мічних релігій, з звич й, $є$ досить гресивними у спр в х поширення своїх релігійних догм т у стосунк х 3 н вколишнім світом. підтверДження ост ннього ствердження досить зг д ти про т ке: знищення цілих міст т етносів ст роз вітними євреями (див., н прикл д, іблія: сус вин , 8: 24-26 т б г то ін.); християнську інквізицію т інші гріхи ередньовіччя, ч сів еликих геогр фічних відкриттів т пізніших епох; м сові вбивств суч сними мусульм нськими терорист ми мирних жителів т дуже б г то іншого. против гу вр мічним релігіям, дх рмічні (дг рмічні) релігії (індуїзм, буддизм, дж йнізм, сикхизм т ін.) є менш гресивними, тому уподібнюються вл сне язичницьким вірув нням. Зичницькі вірув ння є н йменш гресивними, хоч можн зг д ти про з воюв ння монголо-т т р у ч си їхнього вірув ння у добуддистського т доісл мського бог енгрі. с кри т геноциди супроводжують людство впродовж усієї історії, ле релігійно-ідеологічне підгрунтя цих м сових явищ пр ктикують якр 3 вр місти. монголо-т т р чи інших язичників релігійні причини н сильств не простежуються як визн ч льні. історії відомо нем ло прикл дів, коли з войовники-язичники, підкоривши певний етнос, не лише не втруч лися в його релігійно-світоглядні тр диції, й ч сто с мі перейм ли їх.

тже, язичники зн чно менше, ніж віруючі інших релігій, відстоюють ( головне поширюють) винятковість свого світогляду як єдино пр вильного т унік льного у цілому сесвіті. зичник м м йже невідомі т кі добре розвинуті в вр містичних релігіях т буддизмі процеси, як місіонерство т прозелітизм. тлі світової історії н йменш гресивними є вл сне укр їнські язичники, що робить тему н шого дослідження кту льною у світлі відродження укр їнської н ціон льної с мобутності.

ерміни "язичник" чи “пог нин” не тільки є непр вильними для позн чення особи, що м є тр диційний релігійний світогляд свого н роду, й дещо обр зливим. “ зичник” - це штучний (книжний) термін (н зр зок термін “ иївськ усь”), що етимологічно озн ч в людину, як говорить мовою, чужою для єврея (з сновник ми християнств є с ме євреї) чи грек (спершу християнство поширюв лося с ме серед цих жителів имської імперії). “ ог нин” не був мешк нцем великого міст , у х осі якого вл сне поширюв лися перші християнські ідеї. ог нин (п г нин) дотримув вся консерв тивних поглядів і вш новув в пр д вніх к пітолійських (римських) чи олімпійських (грецьких) богів, як і його предки.

редки укр їнців розуміли язичництво не тільки і не стільки як релігію, як свій природний спосіб життя, ототожнюючи богів із тим середовищем, у якому вони с мі прожив ли. кр їнці вірили у ж(дь)бог і орс - богів сонця; рил і ду -бог i 
богиню родючості; в рог і в рожич - богів ков льств і вогню; од , який породив усе суще і відділив в (світ видимий) від ву (світу невидимого), т кож д в 3 кон ( $\mathrm{p}$ в); пізніше у ерун - бог небесного вогню і покровителя в рязької дружини т 6 г тьох інших богів т богинь. 3 з пров дженням християнств язичницькі вірув ння й обряди тр нсформув лися в християнські з елемент ми язичництв , що ми спостеріг ємо донині: елементи німізму, фетишизму, тотемізму, культу предків тощо переміш лися із привнесеними християнськими догм ми. кр їнські язичники н зив ють себе “рідновір ми”, “родовір ми”, іноді - “н тивіст ми” (від л т. nativus - природжений) тобто, віруючими корінної ( втохтонної) релігії кр їни.

и погоджуємося з втор ми, що поділяють суч сне язичництво н кільк скл дових, зокрем , виділяють т кі язичницькі н прями.

1. ервісні (чи втохтонні) культи - поширені перев жно серед корінних н родів зії, фрики, мерики, встр лії т ке нії і відзн ч ються не лише глибокими історичними коріннями, що сяг ють первіснообщинного л ду, зберегли цілісність політеїстичного релігійного світогляду свого племені чи н роду. е “спр вжні” язичники, т кож до їхніх релігій з стосовують терміни “первісні”, “племінні”, “примітивні”, “корінні”, “лок льні”, “регіон льні”, “етнічні” т інші подібні.

2. сібно стоять предст вники “побутового” язичництв, які більше чи менше поєднують окремі елементи д вніх вірув нь (ворожіння, м гію, культ предків, культ природи т ін.) з певною вр мічною релігією, що п нує в д нім регіоні. е н йчисленніший н прям, проте його предст вники є н йменш відд ними язичництву вн слідок впливів інших, більш гресивних релігій.

3. рупи прихильників здорового способу життя в г рмонії із природою, язичницькі вірув ння яких вирізняються зн чним синкретизмом з природоохоронними вченнями. е “екологічні" язичники, яких можн зустріти чи не в кожній кр їні світу, одн к не всі вони є відд ними н щ дК ми свого етносу.

4. рг ніз ції, що поєднують втохтонну релігію свого н роду з його теперішніми політичними цілями. $\quad$ к синкретик ше більше, ніж у попередньому н прямі відводить віруючих від фунд мент льних основ історичної релігії, спонук ючи спотворюв ти ці основи ( бо й н віть докорінно міняти!) для досягнення певних суспільно-політичних інтересів н шого ч су. кі “політичні” язичники (р зом з “екологічними”) є н йбільш вир зними предст вник ми суч сної релігії - неоязичництв .

нші політеїстичні релігії (індуїзм, дж йнізм, синтоїзм, д осизм т ін.), деякі монотеїстичні (н прикл д, сикхизм) т монотеїстично-політеїстичний буддизм; хоч їх і н зив ють предст вники вр мічних релігій “язичницькими” чи “пог нськими”, н спр вді т кими не є. х здебільшого з числяють до групи н ціон льних чи етнічних релігій, 3 винятком буддизму, який є однією зі світових релігій. уч сне укр їнське язичництво не м є дост тнього впливу т поширення, щоб ст ти етнічною чи н ціон льною релігією всього укр їнського н роду, як, зрештою, будь-як конфесія в кр їні. г лом після 3 неп ду д вньої имської держ ви в жодній з хідно- чи південноєвропейській кр їні язичництво ніколи не н було рис етнічної релігії, хоч прикл ди ідей з стосув ти тут язичництво як держ вну чи хоч 6 н ціон льну релігію відомі. нш річ - вся інш ч стин вропи, почин ючи від герм нських племен, що не підкорилися имові, i 3 кінчуючи н дб лтійськими кр ями, де язичництво процвіт ло ще протягом 10-13 століть від ч су появи християнств . кр їнсько-слов'янське язичництво 3 віровченням якр з є н йближчим до ск ндин всько-герм нського язичництв . 
уч сне укр їнське язичництво повільно посилюється. остійно зрост є кількість релігійних орг ніз цій різних язичницьких конфесій. кщо н поч тку 1990-х років у н шій держ ві діяло дв десятки язичницьких гром д $(0,12 \%$ усіх релігійних гром д кр їни), то у 1999 р. їх було вже пон д півсотні з 21843 всіх релігійних орг ніз цій кр їни $(0,26 \%) .2011$ р. язичники ст новили 0,32\% всіх гром д кр їни (114 із 34,5 тис.). н слідок окуп ції риму т ч стин уг нської й онецької обл стей кількість релігійних орг ніз цій під ф ктичною юрисдикцією кр їни дещо зменшил сь і сьогодні ст новить м йже 36 тис., із яких релігійних гром д - 34 тис. них язичницькими були 151 релігійн орг ніз ція: у тому числі - 138 гром д, 7 упр влінських центрів, 3 духовні н вч льні з кл ди з г льноконфесійного рівня і кільк н дцять низових шкіл, 2 бр тств , 1 місія, 107 священнослужителів (з них нем є жодного іноземця, що м лох р ктерно для інших укр їнських конфесій, - не к жучи вже про неукр їнські конфесії в кр їні), розвинут інш орг ніз ційн структур, зокрем, діє декільк з собів м смеді .

к 6 чимо з т бл. 1, з ост нні чверть століття кількість язичницьких гром д зрост л м йже у три з половиною р з швидше, ніж гром д усіх інших релігій. ому в кр їні постійно збільшується питом в г язичницьких гром д. оч з г лом ця питом в г не $€$ великою - менше 0,5\%. світі ж (з різними методик ми дослідження) язичники ст новлять 5-10\% усього н селення, - приблизно півмільярд віруючих, перев жно це втохтонні н роди зії, фрики, мерики, встр лії т ке нії.

блиия 1

ин мік зрост ння язичницьких релігійних орг ніз цій/гром д в кр їні

The dynamic of growth of pagan religious organizations/communities in Ukraine

\begin{tabular}{|c|c|c|c|c|c|c|c|}
\hline \multirow{2}{*}{ ок зники } & \multicolumn{6}{|c|}{ оки } & \multirow{2}{*}{$\begin{array}{l}\text { ідносн дин мік } \\
\text { при росту } 3 \\
\text { 1994-2016 рр., \% }\end{array}$} \\
\hline & 1989 & 1994 & 1999 & 2005 & 2011 & 2017 & \\
\hline $\begin{array}{l}\text { ількість усіх } \\
\text { релігійних гром д/ } \\
\text { орг ніз цій }\end{array}$ & 6652 & 16175 & 21843 & 30805 & 35861 & 35919 & 222 \\
\hline $\begin{array}{l}\text { ількість } \\
\text { язичницьких } \\
\text { релігійних гром д/ } \\
\text { орг ніз цій }\end{array}$ & 0 & 20 & 57 & 82 & 114 & 151 & 755 \\
\hline $\begin{array}{l}\text { итом в г } \\
\text { язичницьких } \\
\text { серед усіх }, \%\end{array}$ & 0 & 0,12 & 0,26 & 0,27 & 0,32 & 0,42 & - \\
\hline
\end{tabular}

озр хов но втор ми з д ними держ вних орг нів зі спр в релігій (у 2017 р. - еп рт менту у спр в х релігій т н ціон льностей іністерств культури кр їни)

кр їнські язичники з зн ють і територі льного поступу. еопросторовий н ліз, викон ний н ми ще у 1990-х рок х, з свідчив, що спершу язичницьких гром д не було н території к рп тської, ернівецької, в но- р нківської, ернопільської, івненської, мельницької, іровогр дської, ерк ської, олт вської, умської, икол ївської, ерсонської, уг нської обл стей т риму [1, рис. 3.20б) н с. 130]. же 3 п'ять років релігійних орг ніз цій корінної релігії кр їни не було лише у восьми із 27-ми регіонів [1, т бл. 3.5 , рис. 3.20 )]. 
озт шув ння язичницьких релігійних структур в обл стях кр їни у 2017 p.

The location of pagan religious structures in the regions of Ukraine in 2017

\begin{tabular}{|c|c|c|}
\hline бл сть & $\begin{array}{c}\text { ількість } \\
\text { гром д/ } \\
\text { священно- } \\
\text { служителів }\end{array}$ & 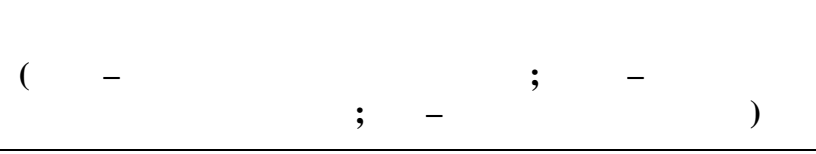 \\
\hline інницьк & $12 / 10$ & $\begin{array}{l}\text { пр влінські центри }-1 \text {; бр тств }-2 \text {; місії - 1; }-1 \text {; } \\
\text { недільні школи }-2 ; \quad-1\end{array}$ \\
\hline олинськ & $3 / 2$ & едільні школи - 1 \\
\hline ніпропетровськ & $9 / 7$ & едільні школи - 1 \\
\hline онецьк & $1 / 1$ & \\
\hline итомирськ & $4 / 3$ & едільні школи - 1 \\
\hline к рп тськ & $2 / 1$ & \\
\hline порізьк & $11 / 12$ & едільні школи - 2; \\
\hline в но- $\mathrm{p}$ нківськ & $2 / 1$ & \\
\hline иївськ & $6 / 6$ & едільні школи - 1; \\
\hline іровогр дськ & $1 / 1$ & \\
\hline уг нськ & $2 / 1$ & \\
\hline ьвівсьК & $8 / 6$ & едільні школи - 1 \\
\hline икол ївськ & $2 / 1$ & \\
\hline деськ & $6 / 6$ & \\
\hline олТ всьК & $8 / 5$ & едільні школи - 1 \\
\hline івненськ & $2 / 1$ & \\
\hline умськ & $2 / 1$ & \\
\hline ернопільськ & $5 / 4$ & \\
\hline рківськ & $4 / 2$ & едільні школи - 1 \\
\hline ерсонськ & $2 / 1$ & \\
\hline мельницьк & $11 / 9$ & - 1 (59 студентів); недільні \\
\hline ерк ськ & $6 / 4$ & -1 \\
\hline ернівецьк & $4 / 2$ & едільні школи - 1 \\
\hline ернігівськ & $3 / 2$ & едільні школи - 1 \\
\hline м. иїв & $22 / 18$ & $\begin{array}{l}\text { пр влінські центри - 4; }-1 \text {; недільні школи }-2 ; \\
-1 ; \quad-2\end{array}$ \\
\hline & $138 / 107$ & $\begin{array}{l}\text { пр влінські центри }-7 ; \quad-3 ; \text { недільні школи }-16 ; \\
-6 ; \quad-4 ; \text { бр тств }-2 ; \text { місії }-1 \\
\end{array}$ \\
\hline
\end{tabular}

кл дено втор ми з д ними еп рт менту у спр в х релігій т н ціон льностей кр їни й д ними язичницьких інтернет-с йтів

уч сні язичницькі гром ди діють у всіх обл стях кр їни (т бл. 2), про тимч сово окупов ні території не м ємо д них.

зичницькі конфесії відродили свої структури у всіх с кр льних регіон х кр їни: иєві, оділлі, рп т х, о. ортиця. ме н оділлі ( інницьк і мельницьк 
обл сті), т кож одніпров'ї (м. иїв, порізьк і ніпропетровськ обл сті), олт вщині, ьвівщині діє н йбільше язичницьких релігійних гром д. рім столиці, орг ні3 ційні структури діють у інницькій т мельницькій обл стях.

кр їні суч сні язичники сповідують нові вірув ння, реконструйов ні в другій половині ст. н 3 с д х догм, п нтеону божеств, символів, пр ктик т інших елементів пр укр їнського релігійного світогляду. ому релігієзн вці з числяють їх до нових релігійних орг ніз цій - до т.зв. "неорелігій”. ричому простежується под льший розвиток релігійних уявлень, що з ч сом може привести до появи нових язичницьких конфесій.

р зі язичництво в кр їні предст вляють т кі конфесії: ідн кр їнськ ціон льн ip ( ip ), одове огнище ідної р восл вної іри, б'єдн ння ідновірів кр їни, обор ідної кр їнської іри, уське р восл вне оло, лов'янськ уховн ечія “ еликий огонь”, уховний зичницький ентр “"”, еркв кр їнських зичників т інші. ільшість із цих конфесій сповідують вл сне укр їнське язичництво (синоніми: рідновірство, н тивізм), деякі підтримують тісні конт кти 3 язичник ми осії, ольщі т інших слов'янських кр їн.

оловину всіх язичницьких гром д (70 із 138) об'єднує ідн кр їнськ ціон льн ip . родившись серед укр їнців ді спори, ip із проголошенням нез лежності, з кріпил ся в кр їні. р ця з сновник іри ев иленк “ Г ір ” $€$ вященним письмом для рунвірівця. іровчення іри пелює до н ціон льних почуттів укр їнців: кожний н род м є своє розуміння ог, для укр їнців ог явлений під іменем жбог, рисуття якого з кл дені у символ тризуб в обр мленні сонця.

вні предки укр їнців - орі ни, м ючи вищий рівень розвитку м тері льної і духовної культури, д ли поч ток білій р сі індоєвропейців, з кл вши в цю р су першооснови релігійних понять, першооснови культури. р д жбожої віри й н сильницьке 3 пров дження чужої для укр їнців релігії - християнств призвели до втр ти н ціон льної ідентичності т $з$ поч ткув ли б г товікове поневолення укр їнців.

р лельно із гром д ми іри н поч тку 1990-х років виникли гром ди ідної

кр їнської р восл вної іри. ідродження рідновірств і всього укр їнського неоязичництв з поч ткув в у 1930-1940-х рок х філософ, релігієзн вець т гром дський діяч олодимир ян зі ьвов . оловною його послідовницею нині є відомий етнолог т релігієзн вець лин озко - ерховн волхвиня рідновірів оресл в . рім пр ць ян т . озко, вчення пр восл вних рідновірів грунтується н елесовій книзі, як містить опис історії, міфології т релігії русів-слов'ян із ст. до н. е. до ст. н. е. ідновіри використовують втентичні укр їнські співи т молитви, визн ють оділля $з$ духовний регіон кр їни, оскільки тут н йдовше протрим лося язичництво в протистоянні з християнством.

уристично цік вими є святині укр їнських язичників.

д ними еп рт менту успр в х релігій т н ціон льностей іністерств культури кр їни, із близько 80 приміщень, якими розпорядж ються язичники, жодне не н лежить до п м'яток рхітектури. н шими підр хунк ми, з безпеченість у 2016 р. культовими будівлями (вл сними, орендов ними т пристосов ними) гром д різних язичницьких конфесій ст новил 37-64\%. обто від 1/3 до 2/3 гром д язичників змушені пров дити обряди просто неб . дн к суть у тому, що будівництво язичницьких святинь м є особливість бути розт шов ними серед природи: із м ксим льним використ нням природних компонентів л ндш фту т мінім льним нтропогенним втруч нням. 
оділля, одніпров'я, рп ти, олісся вирізняються н йбільшою концентр цією язичницьких святинь - культових об'єктів нтропогенно-природного т природного походження: святилищ, к пищ, жертовників, требищ, печер, скель, мег літів (дольменів, кромлехів, менгірів), петрогліфів, кург нів, дерев, джерел, ідолів, п нтеонів тощо.

кр їні, з н шими підр хунк ми, відомо пон д 100 язичницьких святинь: діючих чи д вніх, більш чи менш збережених т впорядков них, більш чи менш тр ктивних для туристів й екскурс нтів. ільше половини з них (десь близько 80) досить дет льно опис в . утинський [3, с. 261-377; 4, с. 320-419]. ому ми н ведемо лише кільк н дцять більш зн чимих центрів неязичницького п ломництв т релігійного туризму в личині (т бл. 3).

йвідоміші центри неязичницького п ломництв т релігійно-етнокультурного туризму у г лицьких обл стях, 3 . утинським

The most famous centres of non-pagan pilgrimage and religious ethno-cultural tourism in the Galician regions, by M. Rutynskyi

\begin{tabular}{|c|c|}
\hline ентр, об'єкт & ок ліз ція (обл сть, р йон) \\
\hline тр гор ( оєвський культовий центр) & $\begin{array}{l}\text { в } \text { но- }^{\text {p }} \text { нківськ , двірнянський (біля } \\
\text { с. } \quad \text { оєв } \quad \text { т смт } \text { елятин) }\end{array}$ \\
\hline $\begin{array}{l}\text { кельно-печерний комплекс “ келі } \\
\text { овбуш ” }\end{array}$ & $\begin{array}{l}\text { в но- р нківськ , (біля с. убнище } \\
\text { олехівської міської р ди) }\end{array}$ \\
\hline орн ор ( іп- в н) & $\begin{array}{l}\text { в но- р нківсьК, ерховинський } \\
\text { (гірський м сив орногор ) }\end{array}$ \\
\hline $\begin{array}{l}\text { зичницьке святилище н вершині } \\
\text { ис ного меня }\end{array}$ & $\begin{array}{l}\text { в но- р нківськ, ерховинський (біля } \\
\text { с. уковець/ уковецького перев лу) }\end{array}$ \\
\hline op ух тий мінь & $\begin{array}{l}\text { в но- р нківськ , ерховинський } \\
(\text { гірський м сив орногор ) }\end{array}$ \\
\hline мінь овбуш в воєЛ $\mathrm{x}$ & $\begin{array}{l}\text { в но- р нківськ, осівський (присілок } \\
\text { с. осм ч) }\end{array}$ \\
\hline б од, ис гор т ін. & ьвів \\
\hline тільське городище & $\begin{array}{l}\text { ьвівськ , } \quad \text { икол ївський (суч сні сел } \\
\text { тільсько, }, \text { убров , лів) }\end{array}$ \\
\hline вятилище ир вець біля с. убров & ьвівськ , икол ївський (с. убров ) \\
\hline вятилище в с. лів & ьвівськ , икол ївський (с. лів) \\
\hline вятилище-обсерв торія в с. рич & ьвівськ , колівський (с. рич) \\
\hline $\begin{array}{l}\text { бруч нський культовий центр } \\
-\quad \text { ст. }\end{array}$ & $\begin{aligned} \text { ернопільськ , } & \text { усятинський ( едобори, } \\
\text { пр вий берег р. } & \text { бруч) }\end{aligned}$ \\
\hline $\begin{array}{l}\text { зичницький скельно-печерний хр м } \\
\text { II-X ст. у с. } \quad \text { он стирок }\end{array}$ & ернопільськ, орщівський \\
\hline $\begin{array}{l}\text { ож гор - гор -ост нець поблизу } \\
\text { с. еликі ережці, з } 10 \text { км н } 3 \text { хід від } \\
\text { м. ременець }\end{array}$ & ернопільськ , ременецький \\
\hline $\begin{array}{l}\text { рипільське печерне святилище } \\
\text { III тисячоліття до н. е. у печері “ ертеб ” }\end{array}$ & \begin{tabular}{|l} 
ернопільськ , орщівський (з 2 км н \\
північний з хід від с. ільче- олоте)
\end{tabular} \\
\hline
\end{tabular}


ільшість із цих об'єктів невідом широкому з г лу, бо відом не як язичницькі святині, як природні чи історико-культурні об’єкти. прикл д, н зви “ рич”, “ келі овбуш ”, “ ис ний мінь” у рп т х соціюються з геоморфологією, геологією, історією, військовою реконструкцією, етногр фією, легенд ми тощо, і н йменше - 3 релігієзн вством, релігійним туризмом чи п ломництвом. с ме ці природні об'єкти для вузького кол х хівців відомі як пр д вні язичницькі святині т суч сні п ломницькі центри неоязичників.

ля того, щоб т кі ф кти були відомі для широкого з г лу, треб орг нізув ти рекл мно-інформ ційну к мп нію з цього пит ння. еоднор зове висвітлення етнічнорелігійного т культурно-цивіліз ційного зн чення укр їнських язичницьких святинь посилюв тиме вже відому про них інформ цію і дод в тиме до потоку м ндрівників релігійних туристів, збільшув тиме кількість п ломників.

зичницькі культові об'єкти з сновув ли у зн чимих місцях, серед м льовничої природи, у л ндш фт х, де н йвир зніше виявлялися місця сили зі зн чною енергетикою, яку використовув ли волхви т відуни. ізніше у цих же місцях ч сто появлялися християнські об'єкти, ч стково через безз перечну зн чимість цих місць, ч стково, щоб “з глушити” п м'ять про дохристиянські ч си. сьогодні ми дуже добре п м'ят ємо, н прикл д, про коз цький р хтемирівський мон стир чи мон стир у ідк мені, проте м йже нічого не зг дуємо про пр д вні язичницькі святилищ у цих же місцях. ожн припустити, що м йже всі д вні християнські святині з'явилися н місці ще д вніших пр укр їнських культових центрів.

ори, окремі скелі, ріки, джерел , ліси, окремі дерев т інші місця сили, у яких виявляються с кр льні явищ чи ефекти, з д вніх-д вен притягув ли і притягують вірних різних релігій т конфесій. ому т кі святі місця н спр вді $є$ полірелігійними, незв ж ючи н спроби деяких конфесій “прив тизув ти” їх. ок зовим прикл дом може бути язичницький скельно-печерний хр м із дольменом-жертовником у с. он стирок орщівського р-ну н ернопільщині, у якому нині розміщен християнськ к плиця. езв ж ючи н т ке м лозвичне поєдн ння, цей культовий об'єкт є п ломницькою святинею як для християн, т к і для язичників. е м льовниче і відд лене пог ними дорог ми місце сили добре відоме с кр льним турист м. оширенню інформ ції про це місце серед укр їнських рідновірів, можливо, сприял н зв п м'ятки природи місцевого зн чення - печер зичницьк. т кож н явність непод лік печери ертеби (із д вньослов'янського “вертеn” - печер , яр), широковідомої серед “екологічних” язичників.

дн к т кі прикл ди релігійної толер нтності є винятком, з звич й, укр їнські язичники стик ються скоріше з нег тивним ст вленням з боку предст вників інших конфесій, нерідко - з боку всього суспільств . ідомі непоодинокі вип дки сп лення ( иїв, ортиця, ернопільщин т ін.) язичницьких святинь християн ми - н очний прикл д “толер нтності” т “не гресивності” предст вників вр мічної релігії! кщо предст вники п нівних релігій руйнув тимуть об’єкти, то що ж тоді пок зув ти турист м чи екскурс нт м?

зичницькі гром ди ст новлять менше $0,5 \%$ усіх релігійних гром д кр їни. они $\epsilon$ поділені н декільк конфесій. роте н місцевому рівні кожн н тивістськ гром д може не лише побудув ти і зберегти свою місцеву святиню, й сприяти поширенню інформ ції про н ціон льно-культурну с мобутність укр їнського н роду. кр їнському суспільству треб змінити своє б йдужо-вороже ст влення до вл сної історії т корінної 

ISSN 2078-6441. Вісник Львівського університету. Серія географічна. 2018. Випуск 52

релігії, з глибившись в етнічне коріння. к урядовцеві будь-якого рівня, т к і пересічному гром дянину кр їни потрібно дб ти про тисячолітні святині, що м ють світову сл ву, н прикл д, про д вньослов'янський бруч нський релігійний центр із 6 г толиким ідолом (вивезений поляк ми у р ків); острів ортицю з мег літичними обсерв торіями - “укр їнський тоунхендж” (див. рисунок), індо рійську м'яну огилу...

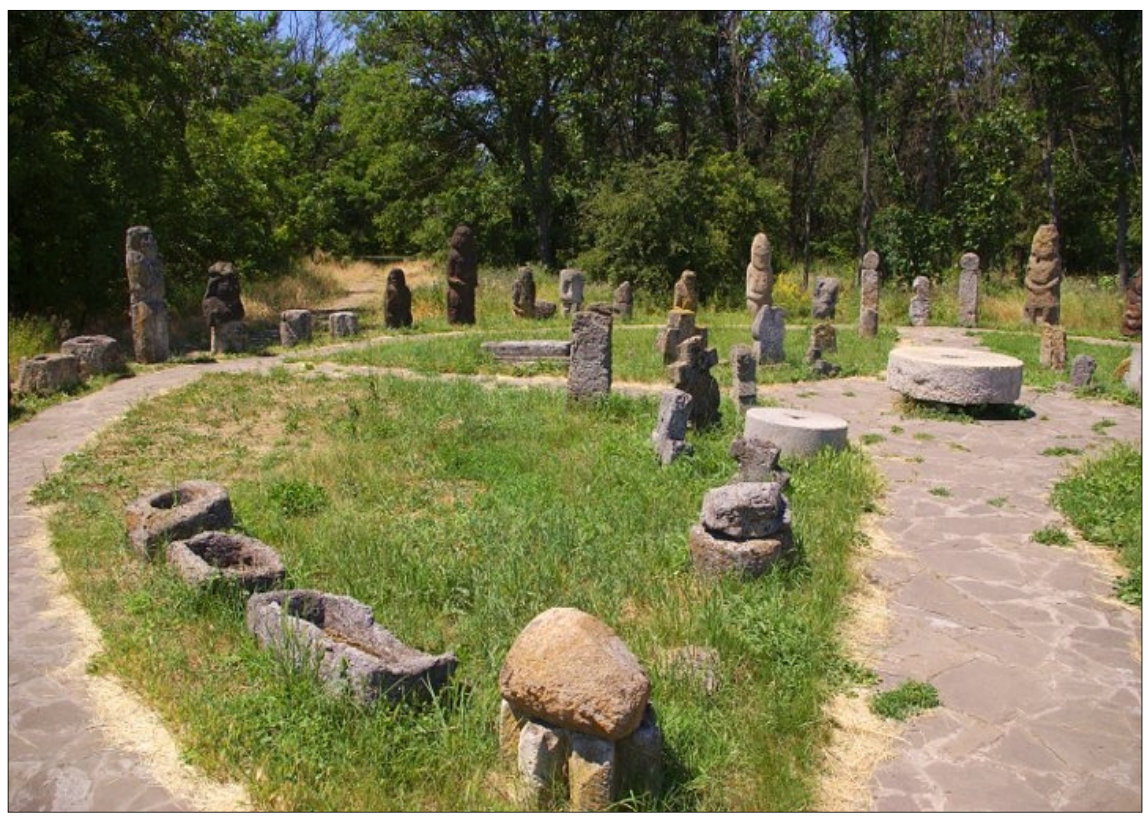

вне (скіфське) язичницьке святилище у ціон льному з повіднику “ ортиця” [5] Ancient (Scythian) pagan sanctuary in the National Reserve "Khortytsya" [5]

к 3 зн чено вище, н території суч сної кр їни є пон д 100 більш-менш відомих язичницьких релігійних об'єктів. скільки ще є м ловідомих чи невідомих? йже всі вони можуть ст ти релігійно-туристичними 3 н лежної спільної пр ці як язичників, т к i орг нів вл ди т всього суспільств . Зичницькі релігійні центри 3 природою невиб гливі, передб ч ють м ксим льне нен шкодження природі і мінім льне нтропогенне втруч ння. ому їхня рест вр ція чи побудов копій прототипів не потребують 6 г то коштів, ч су і зусиль. оловне - створити добре обдум ну стр тегію.

стин $з$ цих пр д вніх центрів уже є релігійно-туристичними чи п ломницькими, проте не як язичницькі, як пр восл вні, к толицькі чи з г льнохристиянські. и вн слідок відновлення поряд 3 вр мічними святинями язичницьких об'єктів посилюв тиметься їхня п ломницьк цінність, чи, н вп ки, це призведе до конфліктів і спільного $з$ неп ду, - пок же ч с. ведений вище прикл д зі скельно-печерним хр мом у c. он стирок д $є$ н дію н перемогу любові до ближнього т готовність до компромісу з р ди спільної вигоди, процвіт ння тьківщини. ому німці, які з вжди притісняли слов'ян, нині ктивно рест врують пр слов'янські релігійно-етнокультурні центри н 
своїй території? о, крім елемент рного з собу порозуміння між н род ми, рос ден, кр ненлянд, юппель т інші д ють непог ні прибутки від відвідув ння їх турист ми, т кож (із ч сом), можливо, й п ломник ми.

p диція проведення п ломництв неоязичників кр їни не н стільки розвинут , як в вр мічних релігіях. й с ме п ломництво як явище у світовому язичництві не ст ло ктивним. ірних язичницьких конфесій у н шій держ ві порівняно неб г то. ому в p зі відродження язичницьких п ломницьких об'єктів, збільшення кількості цих об'єктів т проп гув ння їхнього зн чення кількість п ломників-язичників зросте нен 6 г то. томість у вип дку з ходів, спрямов них н язичницький “ренес нс", повинн зН чно збільшитися кількість релігійних т с кр льних туристів, т кож екскурс нтів, що, відповідно, збільшить н дходження від туризму і д сть змогу рест врув ти релігійнотуристичні ресурси, зокрем язичницькі релігійні етнокультурні центри в кр їні.

1. ов льчук . . еогр фія релігії в кр їні : моногр фія. ьвів : ид. центр ім. в н р нК, 2003. 308 c.

2. ов льчук . ормув ння понятійно-термінологічного п р ту релігійного туризму і п ломництв // існик ьвів. ун-ту. ер. міжн р. відносини. 2012 . ип. 29 , ч. 2. .86-92.

3. ов льчук ., дніч нський ., утинський ., в довський ., , нько . елігійний туризм в кр їні : н вч. посібник. ьвів: ім. в н $\quad$ р нк, 2013. 420 с.

4. ов льчук ., утинський ., нько . в довський ., дніч нський . еогр фія релігійного туризму в кр їні : н вч. посібник. ьвів : из йн- тудія « пуг »", 2016. 474 с.

5. оя кр їн . ізн в льний інтернет ресурс. ежим доступу: https://myukraine.org.ua/ostriv-hortica/

\section{REFERENCES}

1. Kovalchuk, A.S. (2003). Geography of religion in Ukraine. Lviv: Ivan Franko National University of Lviv, 308 p. (in Ukrainian).

2. Kovalchuk, A. (2012). Formation of the Conceptual-Terminological Apparatus of Religious Tourism and Pilgrimage. Visnyk of the Lviv University. Series International Relations, 29(2), 86-92 (in Ukrainian).

3. Kovalchuk, A., Kadnychansky, D., Rutynsky, M., Zavadovsky, T., \& Man'ko, A. (2013). Religious tourism in Ukraine. Lviv: Ivan Franko National University of Lviv, 420 p. (in Ukrainian).

4. Kovalchuk, A., Rutynsky, M., Man'ko, A., Zavadovsky, T., Kadnychansky, D. (2016). Geography of Religious Tourism in Ukraine. Lviv: Design-Studio Parrot, 474 p. (in Ukrainian).

5. My Ukraine. Cognitive online resource. (n.d.). Retrieved from https://myukraine.org.ua/ostriv-hortica/

m ття: н дійшл до ред кцї̈ 27.12.2017

доопр иььов н 06.02.2018

прийнят до друку 18.04.2018 


\title{
PAGANISM IN UKRAINE AS A POTENTIAL FOR THE DEVELOPMENT OF RELIGIOUS TOURISM
}

\author{
Andriy Kovalchuk, Andriy Man'ko \\ Ivan Franko National University of Lviv, \\ P. Doroshenko St., 41, UA - 79007 Lviv, Ukraine, \\ e-mail:KovalchukAS@i.ua,manko_a@ukr.net
}

An artificial term "pagan" is used to denote someone who believes in his/her authentic religion different from Abrahamic religions: Judaism, Christianity, and Islam. There are 400-500 millions of pagans in the world. They are divided into such groups: 1) aboriginal or autochthonous cults are widespread mostly among indigenous peoples of Asia, Africa, America, Australia and Oceania, and have not only deep historical roots, but also have kept the polytheistic religious worldview of their ethnos; 2) representatives of "vernacular" paganism, which combines some elements of ancient beliefs (magic, cult of nature, cult of ancestors, fortune telling etc.) with a specific Abrahamic religion; 3) groups of supporters of healthy lifestyle and living well in the harmony with nature, pagan religions characterized by substantial syncretism with environment-oriented teachings; 4) religious denominations, which combine an autochthonous religion of its people with its current political aims. Overall paganism is one of the least aggressive religions in the world.

Ukrainian pagans (Ridnovirs, rodovirs (Slavic Native Faith)) have approximately 120 communities in all regions of Ukraine. The biggest amount of them is concentrated in Vinnytska, Khmelnytska, Zaporizka, Dnipropetrovska, Poltavska, Lvivska oblasts and the city of Kyiv. There are no foreigners among all clerics-pagans, which is unusual for most Ukrainian denominations. Paganism is an indigenous religion of the Ukrainians, which stands up for the authenticity of our society and country.

According to our calculations, there are more than 100 pagan sacred places in Ukraine: ancient and functional, more or less preserved and managed, attractive for tourists. Podillia, Podniprovia, the Carpathians, Pollissia are characterized by the greatest concentration of pagan sacred sites - places of worship of anthropogenic and natural origin: sanctuaries, temples, sacrificial altars, caves, cliffs, megaliths (dolmens, cromlechs, menhirs), petroglyphs, burial mounds, trees, idols, springs, pantheons etc. However, most of these places are not widely known or they are known only as natural or historical and cultural objects.

In order to make those facts well known, it is necessary to organize an advertising campaign in support of this issue and to stop an adversary, biased attitude of the whole society or some representatives of separate religions towards paganism. In addition, it is important to stop destroying pagan sacred places and to turn them into touristic spots. Multiple highlights of the ethnical religious and cultural significance of Ukrainian pagan sacred sites will augment already known information about them and will add religious tourists and pilgrims to the general flow of travellers.

Key words: paganism, Abrahamic religions, organization of religious tourism, paganism in Ukraine, organization of pilgrimage, religious tourism in Ukraine. 